\title{
Models for Empirical Analysis of Economic Growth in Bangladesh: Integrating Economic, Financial and Accounting Variables
}

\author{
Professor Dilip Kumar Sen
}

\begin{abstract}
This research study has analyzed the integration of economic, financial and accounting variables in the perspective of economic growth and development of Bangladesh. It is an endeavor to examine whether the integration of the above referred three types of variables has any effect on the economic growth rate of Bangladesh. Thirty years' data of economic, financial and accounting variables have been taken into consideration for the purpose of regression analysis aimed at examining the result of the study. The result of the study is that the selected economic, financial and accounting variables can jointly explain economic growth more accurately than by using economic variables alone. In other words, the integration of the above referred three types of variables is more effective than taking only economic variables alone for explaining the economic growth rate of a nation.
\end{abstract}

Keywords: Economic growth, economic, financial and accounting variables, integration and regression analyses.

\section{Introduction}

In its simplest definition "economic growth" is the rate of increase in the national income. National income, a standard measure of which is the gross domestic product (GDP), is obtained from the financial measurement of the total production in the country. The growth in the national income is related to many factors. Conventional studies have explained economic growth through economic variables such as consumption expenditure, investment expenditure, government expenditure, net exports, rate of inflation, etc.

This paper aims to provide an empirical analysis of the effect of selected variables which can be classified into three distinct categories: economic variables, accounting variables and financial variables. A comparison is also made with a separate model that explains the change in economic growth using economic variables only (excluding the accounting and financial variables), in order to examine whether the amalgamation of all three variables collectively can better explain economic growth.

\section{Literature Review}

Conventional studies have mostly explained economic growth through economic variables only. Shourie (1972) was among the earlier discussants on macroeconomic model building for developing countries. Haque, Lahiri and Montiel (1990) conducted a macroeconometric analysis of 31 developing countries. A more recent study (Valadkhani, 2005) highlights some important lessons from more than half a century of model-building particularly in the context of Asian countries.

Dr. Dilip Kumar Sen is Professor of Accounting \& Finance, School of Business, Independent University, Bangladesh (IUB), prof_dilipsen@yahoo.com

\begin{tabular}{llll|l}
\hline Journal of Independent Studies and Research - MSSE & Volume 10 & Number 1 & January 2012 & 125
\end{tabular} 
There have been substantial macroeconomic studies on individual countries in the SAARC region as well, including India (Desai, 1973; Pani, 1984; Jadhav, 1990; Krishnamurthy, 2002; Mallick, 2004), Bangladesh (Rashid, 1981; Parikh, 1983; Rahman \& Shilpi, 1996; Hossain \& Razzaque, 2003; Maroney, Hassan, Basher \& Isik, 2004), Sri Lanka (Colombage, 1992), Nepal (Sapkota \& Sharma, 1998; Ra \& Rhee, 2005) and Pakistan (Naqvi, Khan, Khilji \& Ahmed, 1983; Kazmi, 1992; Iqbal \& Zahid, 1998; Khan \& Din, 2011). Rashid's (1981) analysis was among the early macro-econometric models in the context of independent Bangladesh, although no policy implications could be carried out at that stage. Parikh (1983) examined the effects of monetary and fiscal stimulus on the structure of the Bangladesh's economy. Rahman and Shilpi (1996) developed a macroeconometric model for the Bangladesh economy incorporating five economic blocks: expenditure, fiscal, money and finance, trade and aggregate supply blocks. In a similar fashion, Hossain and Razzaque's (2003) study on the Bangladesh economy segregated the economic activities into six blocks: production, investment, private consumption, external sector, government, and money and price blocks. Maroney et al. (2004) incorporated nine key macroeconomic variables in their macroeconometric model of the Bangladesh economy, concluding that monetary policy has a more important role to play than fiscal policy.

There have also been studies to explain economic activity using financial variables, particularly the stock index, and the yield from bonds and stocks as well as foreign direct investment, in an attempt to predict future recessions. The conclusions have been varied. Rudebusch and Williams (2008) postulated that a simple model for predicting recessions that uses only real-time yield curve information would have produced better forecasts of recessions at horizons beyond two quarters. Harvey (1989) further proposed that bond market variables provide a better insight into predicting economic growth than stock market variables, a view also shared by Fink, Haiss and Hristoforova (2003). On the other hand, studies in China (Maosheng \& Weiguo, 2002) and Korea (Kwon \& Shin, 1999) established that the expansion of the stock market had a weak effect on economic growth. Stock and Watson (2003) and Espinoza, Fornari and Lobmardi (2009) conclude that financial variables do not help in forecasting real activity in the euro area.

Studies in the SAARC region have also had mixed outcomes. Padhan (2007), Agrawalla and Tuteja (2007) maintain that a stable and well-developed stock market could enhance economic activity and promote long run economic growth in India. On the other hand, a study in Pakistan (Husain \& Mahmood, 2001) does not characterise the stock market as a leading indicator of economic activity in Pakistan. Separate studies in Sri Lanka have yielded conflicting findings regarding the impact of foreign direct investment on economic growth. Athukorala (2003) found that FDI inflows do not exert an independent influence on economic growth in Sri Lanka, whereas Balamurali and Bogahawatte (2004) maintain that foreign direct investment does independently exert an influence on economic growth. Shimul, Abdullah and Siddiqua (2009) postulated that FDI and openness were not significantly causing the GDP per capita in Bangladesh both in the short and long run.

None of the studies thus far has taken an integrated approach to explain economic growth, using economic, accounting and financial variables, which this study aims to do in the context of Bangladesh.

126 January 2012 $\quad$ Volume 10 Number 1 Journal of Independent Studies and Research - MSSE 


\section{Data and Methodology}

The variables in consideration have been classified into three groups: economic variables, accounting variables, and financial variables. In this study, a regression analysis has been constructed for five separate models. In all of the models, the growth rate has been considered to be the dependent variable. In this study, data and operational definition of all variables in the regression analysis have been taken from the World Bank's database of World Development Indicators and Global Development Finance, as well as The University Grants Commission of Bangladesh.

The first two models attempt to explain the growth rate in Bangladesh using changes in the economic variables only:

Model-1: $\Delta \mathrm{GDP}_{\mathrm{t}}=\mathrm{f}\left(\Delta \mathrm{C}_{\mathrm{t}}, \Delta \mathrm{I}_{\mathrm{t}}, \Delta \mathrm{G}_{\mathrm{t}}, \Delta \mathrm{NX}_{\mathrm{t}}, \Delta \mathrm{MS}_{\mathrm{t}}\right)$. It incorporates the variables used in conventional macroeconomic models.

Model-2: $\Delta \mathrm{GDP}_{\mathrm{t}}=\mathrm{f}\left(\Delta \mathrm{G}_{\mathrm{t}}, \Delta \mathrm{MS}_{\mathrm{t}}\right)$. It incorporates only changes in government spending and money supply, the two major instruments of government fiscal policy and monetary policy respectively.

The last three models (Model-3, Model-4A and Model-4B) attempt to explain the growth rate in Bangladesh using a combination of economic, financial and accounting variables.

\section{Model-3:}

$\Delta \mathrm{GDP}_{\mathrm{t}}=\mathrm{f}\left(\Delta \mathrm{C}_{\mathrm{t}}, \Delta \mathrm{I}_{\mathrm{t}}, \Delta \mathrm{G}_{\mathrm{t}}, \Delta \mathrm{NX}_{\mathrm{t}}, \Delta \mathrm{MS}_{\mathrm{t}}, \Delta \mathrm{FDI}_{\mathrm{t}}, \Delta \mathrm{ST}_{\mathrm{t}}, \Delta \mathrm{CC}_{\mathrm{t}}, \Delta \mathrm{RQ}_{\mathrm{t}}, \Delta \mathrm{VA}_{\mathrm{t}}, \Delta \mathrm{CD}_{\mathrm{t}}, \Delta \mathrm{AF}_{\mathrm{t}}\right)$. It incorporates all the economic variables, as well as the financial variables FDI and $\mathrm{ST}$, and accounting variables $C C, R Q, V A, C D$ and $A F$.

Model-4A: $\Delta G D P_{t}=f\left(\Delta G_{t}, \Delta M S_{t}, \Delta F D I_{t}, \Delta S T_{t}, \Delta R Q_{t}, \Delta A F_{t}\right)$. It incorporates six economic, financial and accounting variables. Here financial variables are $\Delta F D I_{t}, \Delta S T_{t}$; and accounting variables are $\Delta R Q_{t}, \Delta A F_{t}$. The remaining are economic variables.

Model-4B: $\Delta G D P_{t}=f\left(\Delta G_{t}, \Delta M S_{t}, \Delta F D I_{t}, \Delta S T_{t}, \Delta A F_{t}\right)$. It incorporates five economic, financial and accounting variables. Here also the same financial variables of Model- $4 \mathrm{~A}$ are available, but only one accounting variable $\Delta A F_{t}$ of Model-4A remains in this model 4B. The other two are economic variables.

Details on the definition and measurements of the variables are as follows:

\subsection{The Dependent Variable}

Gross Domestic Product (GDP) at purchaser's prices is the sum of gross value added by all resident producers in the economy plus any product taxes and minus any subsidies not included in the value of the products. It is calculated without making deductions for depreciation of fabricated assets or for depletion and degradation of natural resources. Data are in constant 2000 U.S. dollars. Dollar figures for GDP are converted from domestic currencies using 2000 official exchange rates. 
In the model, the growth rate, or the rate of change of GDP, has been computed as follows:

$$
\Delta \mathrm{GDP}_{\mathrm{t}}=\frac{\mathrm{GDP}_{\mathrm{t}}-\mathrm{GDP}_{\mathrm{t}-1}}{\mathrm{GDP}_{\mathrm{t}-1}}
$$

\subsection{The Independent Variables}

\subsubsection{Economic Variables}

The conventional economic variables that have been mostly used in the past studies have also been used for this model. The data used for Bangladesh are for the years from 1980 to 2009. The economic variables and their explanations are as follows:

Household final consumption expenditure $(C)$ is the market value of all goods and services, including durable products (such as cars, washing machines, and home computers), purchased by households. It excludes purchases of dwellings but includes imputed rent for owner-occupied dwellings. It also includes payments and fees to governments to obtain permits and licenses. Here, household consumption expenditure includes the expenditures of nonprofit institutions serving households. Data are in constant 2000 U.S. dollars. In the model, the rate of change of $C$ has been computed as follows:

$$
\Delta \mathrm{C}_{\mathrm{t}}=\frac{\mathrm{C}_{\mathrm{t}}-\mathrm{C}_{\mathrm{t}-1}}{\mathrm{C}_{\mathrm{t}-1}}
$$

Gross capital formation (I) (formerly gross domestic investment) consists of outlays on additions to the fixed assets of the economy plus net changes in the level of inventories. Fixed assets include land improvements (fences, ditches, drains, and so on); plant, machinery, and equipment purchases; and the construction of roads, railways, and the like, including schools, offices, hospitals, private residential dwellings, and commercial and industrial buildings. Inventories are stocks of goods held by firms to meet temporary or unexpected fluctuations in production or sales, and "work in progress." Net acquisitions of valuables are also considered capital formation. Data are in constant 2000 U.S. dollars. In the model, the rate of change of I has been computed as follows:

$$
\Delta \mathrm{I}_{\mathrm{t}}=\frac{\mathrm{I}_{\mathrm{t}}-\mathrm{I}_{\mathrm{t}-1}}{\mathrm{I}_{\mathrm{t}-1}}
$$

General government final consumption expenditure (G) includes all government current expenditures for purchases of goods and services (including compensation of employees). It also includes most expenditure on national defense and security. Data are in constant 2000 U.S. dollars. In the model, the rate of change of $G$ has been computed as follows:

$$
\Delta \mathrm{G}_{\mathrm{t}}=\frac{\mathrm{G}_{\mathrm{t}}-\mathrm{G}_{\mathrm{t}-1}}{\mathrm{G}_{\mathrm{t}-1}}
$$

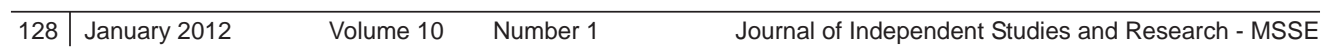


Net exports of goods and services (NX) represent the value of all goods and other market services provided to the rest of the world, less the value of all goods and other market services received from the rest of the world. They include the value of merchandise, freight, insurance, transport, travel, royalties, license fees, and other services, such as communication, construction, financial, information, business, personal, and government services. They exclude compensation of employees and investment income and transfer payments. Data are in constant 2000 U.S. dollars. Since all values of NX are negative, the absolute value has been used in the denominator to determine the relative percentage change in NX. In the model, the rate of change of NX has been computed as follows:

$$
\Delta \mathrm{NX}_{\mathrm{t}}=\frac{\mathrm{NX}_{\mathrm{t}}-\mathrm{NX}_{\mathrm{t}-1}}{\left|\mathrm{NX}_{\mathrm{t}-1}\right|}
$$

Money supply (MS) is the sum of currency outside banks and demand deposits other than those of central government. This series, frequently referred to as M1 is a narrower definition of money than M2. Data are in current local currency. In the model, the rate of change of MS has been computed as follows:

$$
\Delta \mathrm{MS}_{\mathrm{t}}=\frac{\mathrm{MS}_{\mathrm{t}}-\mathrm{MS}_{\mathrm{t}-1}}{\mathrm{MS}_{\mathrm{t}-1}}
$$

\subsubsection{Financial Variables}

The financial variables include data for Bangladesh for the years 1980 to 2009 . The variables in this category reflect the conventional financial variables used to explain economic growth. The financial variables and their explanations are as follows:

Foreign direct investment (FDI) refers to net inflows of investment to acquire a lasting management interest (10 per cent or more of voting stock) in an enterprise operating in an economy other than that of the investor. It is the sum of equity capital, reinvestment of earnings, other long-term capital, and short-term capital as shown in the balance of payments. This series shows total net, that is, net foreign direct investment in the reporting economy from foreign sources less net foreign direct investment by thereporting economy to the rest of the world. Data are in current U.S. dollars. In the model, the rate of change of FD has been computed as follows:

$$
\Delta \mathrm{FDI}_{\mathrm{t}}=\frac{\mathrm{FDI}_{\mathrm{t}}-\mathrm{FDI}_{\mathrm{t}-1}}{\mathrm{FDI}_{\mathrm{t}-1}}
$$

Stocks traded (ST) refers to the total value of shares traded during the period. Data are in current U.S. dollars. In the model, the rate of change of ST has been computed as follows:

$$
\Delta \mathrm{ST}_{\mathrm{t}}=\frac{\mathrm{ST}_{\mathrm{t}}-\mathrm{ST}_{\mathrm{t}-1}}{\mathrm{ST}_{\mathrm{t}-1}}
$$




\subsubsection{Accounting Variables}

The accounting variables incorporate several indicators developed by Kaufmann, Kraay and Mastruzzi (2010) with regard to governance, and include data for Bangladesh for the years 1980 to 2009. Since one of the Millennium Development Goals is to control the rate of carbon dioxide emissions, Carbon dioxide emissions per capita has been considered a variable that accounts for the state of the environment, and as such, has been regarded as an accounting variable, as a higher carbon dioxide emissions would add to the cost of degradation to the environment. The accounting variables and their explanations are as follows:

Control of Corruption (CC) is an accounting variable that captures perceptions of the extent to which public power is exercised for private gain, including both petty and grand forms of corruption, as well as "capture" of the state by elites and private interests. Estimate gives the country's score on the aggregate indicator, in units of a standard normal distribution, i.e. ranging from approximately -2.5 to 2.5 . Since all values of all the governance indicators: $C C, R Q$ and VA, are negative, the absolute value has been used in the denominator to determine the relative percentage change in the governance indicators. In the model, the rate of change of CC has been computed as follows:

$$
\Delta \mathrm{CC}_{\mathrm{t}}=\frac{\mathrm{CC}_{\mathrm{t}}-\mathrm{CC}_{\mathrm{t}-1}}{\left|\mathrm{CC}_{\mathrm{t}-1}\right|}
$$

Regulatory Quality (RQ) might also come under the fold of accounting variables. It captures perceptions of the ability of the government to formulate and implement sound policies and regulations that permit and promote private sector development. Estimate gives the country's score on the aggregate indicator, in units of a standard normal distribution, i.e. ranging from approximately -2.5 to 2.5 . In the model, the rate of change of $R Q$ has been computed as follows:

$$
\Delta \mathrm{RQ}_{\mathrm{t}}=\frac{\mathrm{RQ}_{\mathrm{t}}-\mathrm{RQ}_{\mathrm{t}-1}}{\left|R \mathrm{R}_{\mathrm{t}-1}\right|}
$$

Voice and Accountability (VA) captures perceptions of the extent to which a country's citizens are able to participate in selecting their government, as well as freedom of expression, freedom of association, and a free media. Estimate gives the country's score on the aggregate indicator, in units of a standard normal distribution, i.e. ranging from approximately -2.5 to 2.5 . In the model, the rate of change of VA has been computed as follows:

$$
\Delta \mathrm{VA}_{\mathrm{t}}=\frac{\mathrm{VA}_{\mathrm{t}}-\mathrm{VA}_{\mathrm{t}-1}}{\left|\mathrm{VA}_{\mathrm{t}-1}\right|}
$$

Carbon dioxide emissions (CD) may be considered an environmental accounting variable. These stem from the burning of fossil fuels and the manufacture of cement. They include carbon dioxide produced during consumption of solid, liquid, and gas fuels

130 January 2012 $\quad$ Volume $10 \quad$ Number $1 \quad$ Journal of Independent Studies and Research - MSSE


and gas flaring. Carbon dioxide emissions have been measured in metric tons per capita.

In the model, the rate of change of $\mathrm{CD}$ has been computed as follows:

$$
\Delta \mathrm{CD}_{\mathrm{t}}=\frac{\mathrm{CD}_{\mathrm{t}}-\mathrm{CD}_{\mathrm{t}-1}}{\mathrm{CD}_{\mathrm{t}-1}}
$$

Accounting and Finance graduates' expertise (AF): Accounting as well as finance and banking students passing out from the universities every year as successful and worthy graduates are the most important human assets of different industrial and banking organizations in Bangladesh. Needless to say, National Board of Revenue (NBR) immensely benefits from their valued expertise in formulating policies of increasing revenue in the National Exchequer. Obviously, their contribution to enhancing national wealth seems remarkable. The inextricable link of Accounting and Finance experts with the country's national economic policy can, therefore, be hardly ignored (Enthoven et al., 1978; Enthoven, 1982, 1985; Parry \& Khan, 1984; Schultz, 1989 \& Williams 1991). The truth value of this idea might capture perceptions of the ability of the government to formulate and implement sound economic policies for stimulating economic growth and development. In the model, the rate of change in AF has been computed as follows:

$$
\Delta A F_{t}=\frac{A F_{t}-A F_{t-1}}{A F_{t-1}}
$$

\section{Findings and Discussion}

In the regression analysis comprising five models, particular emphasis has been given to the coefficient of determination $\left(R^{2}\right)$ and the $p$-values for both the independent variables and for the model as a whole. Since the data span 30 years, which is quite large, comparison can be made using the coefficient of determination $\left(R^{2}\right)$ instead of adjusted coefficient of determination $\left(R^{2}\right)$. Simultaneously, there follows a school of thought which suggests that adjusted R-Square should be used to measure 'goodness of fit' in a model that contains more than one independent variable, since simple RSquare systematically overstates 'goodness of fit' in a model with more than one independent variable ( Mc Quarrie and Chih-Ling,1998; Hosmer, 2000). So here we are keeping both R-Square and adjusted R-Square (R-bar Square) for the readers' convenience. $R^{2}$ measures the proportion or percentage of the total variation in economic growth explained by the regression model (Gujarati, 2003), given the sample size and the number of variables. Hence, the higher $\mathrm{R}^{2}$, the better would be the model in terms of explaining the change in economic growth. The $p$-value indicates the observed or exact level of significance (Gujarati, 2003). Hence the p-value for an individual variable determines whether the individual variable is statistically significant in explaining economic growth. The $p$-value for the model determines whether all the variables used in the model are jointly significant in explaining economic growth. A lower $p$-value indicates a higher level of significance. The regression coefficients of the independent variables estimate the expected impact of these variables on economic growth, with positive coefficients indicating a positive impact on growth.

The first two models attempt to explain the growth rate in Bangladesh using changes in the economic variables only.

\begin{tabular}{llll|l}
\hline Journal of Independent Studies and Research - MSSE & Volume 10 & Number 1 & January 2012 & 131
\end{tabular}




\section{Model-1:}

$$
\begin{aligned}
& \Delta \mathrm{GDP}_{\mathrm{t}}=0.0266+0.289 \Delta \mathrm{C}+0.0828 \Delta \mathrm{I}+0.0395 \Delta \mathrm{G}-0.00204 \Delta \mathrm{NX}+0.0216 \Delta \mathrm{MS} \\
& \mathrm{p} \text {-values } \rightarrow \quad(0.004) \quad(0.316) \quad(0.337) \quad(0.756) \\
& R^{2}=0.485, F=4.330, p \text {-value }=0.006, \text { Adjusted } R \text { Square }=0.373 .
\end{aligned}
$$

Model-2:

$$
\begin{aligned}
& \Delta \mathrm{GDP}_{\mathrm{t}}=0.0362+0.0804 \Delta \mathrm{G}+0.0518 \Delta \mathrm{MS} \\
& \mathrm{p} \text {-values } \rightarrow \quad(0.043) \quad(0.024) \\
& R^{2}=0.237, F=4.038, p \text {-value }=0.030, \text { Adjusted } R \text { Square }=0.178 .
\end{aligned}
$$

(In model 2 we have not included the explanatory variables $\Delta \mathrm{C}, \Delta \mathrm{l}$ and $\Delta \mathrm{NX}$. Both the coefficients of $\Delta \mathrm{G}$ and $\Delta \mathrm{MS}$ become significant at $5 \%$ level.)

It can be seen that from the first model that shows economic growth as a function of consumption, investment, government spending, net export and money supply, only consumption is statistically significant in explaining growth. Furthermore, looking at the $p$-value for the model as a whole, all the variables are jointly significant in predicting growth. The $\mathrm{R}^{2}$ value indicates that the variables together account for less than half the variation in economic growth, at $48.5 \%$.

Non-significance of the effect of $\Delta \mathrm{G}$ and $\Delta \mathrm{MS}$ in the first equation is due to inclusion of $\Delta \mathrm{C}$, which has a strong influence on $\Delta \mathrm{GDP}$. This can be seen by not incorporating $\Delta \mathrm{C}$ in the regression equation as shown in Model-2. In the second model, only two variables $\Delta \mathrm{G}$ and $\Delta \mathrm{MS}$, have been included to reflect government fiscal policy and monetary policy respectively. These two variables together accounted for $23.7 \%$ of the variation in economic growth, with both government consumption expenditure and money supply being statistically significant, and the regression coefficient suggests that higher government consumption expenditure and money supply contribute to economic growth. The two variables are jointly significant in explaining the variation in economic growth.

The last three models (that is, Model 3, Model 4A and Model 4B) attempt to explain the growth rate in Bangladesh using a combination of economic, financial and accounting variables.

\section{Model-3:}

$$
\begin{aligned}
& \Delta \mathrm{GDP}_{\mathrm{t}}=0.0329+0.150 \Delta \mathrm{C}+0.0285 \Delta \mathrm{l}+0.0606 \Delta \mathrm{G}-0.00182 \Delta \mathrm{NX}+0.0489 \Delta \mathrm{MS} \\
& p \text {-values } \rightarrow \quad(0.245) \quad(0.772) \quad(0.194) \quad(0.815) \quad(0.083) \\
& +0.00156 \Delta \mathrm{FDI}+0.00097 \Delta \mathrm{ST}-0.00258 \Delta \mathrm{CC}+0.00032 \Delta \mathrm{RQ}-0.00034 \Delta \mathrm{VA} \\
& \begin{array}{lllll}
(0.056) & (0.315) & (0.887) & (0.945) & (0.985)
\end{array} \\
& +0.00049 \Delta \mathrm{CD}-0.0986 \Delta \mathrm{AF} \\
& \text { (0.989) (0.056) } \\
& R^{2}=0.657, F=2.552, p \text {-value }=0.041 \text {, Adjusted } R \text { Square }=0.373 .
\end{aligned}
$$

132 January $2012 \quad$ Volume $10 \quad$ Number $1 \quad$ Journal of Independent Studies and Research - MSSE 


\section{Model-4A:}

$$
\begin{aligned}
& \Delta \mathrm{GDP}_{\mathrm{t}}=0.0367+0.0793 \Delta \mathrm{G}+0.0671 \Delta \mathrm{MS}+0.00204 \Delta \mathrm{FDI}+0.00125 \Delta \mathrm{ST} \\
& \mathrm{p} \text {-values } \rightarrow \quad(0.028) \quad(0.002) \quad(0.001) \quad(0.060) \\
& -0.00079 \Delta R Q-0.116 \Delta A F
\end{aligned}
$$

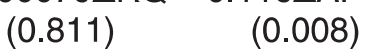

$$
\begin{aligned}
& R^{2}=0.607, F=5.664, p \text {-value }=0.001, \text { Adjusted } R \text { Square }=0.500 .
\end{aligned}
$$

\section{Model-4B:}

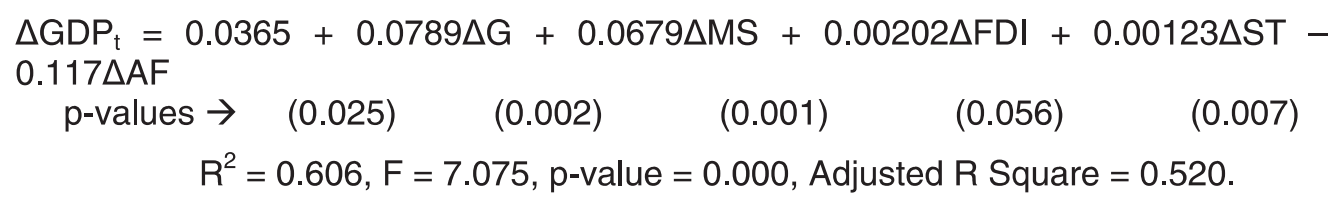

Although the third model, which incorporates all the economic, accounting and financial variables, explains $65.7 \%$ of the total variation in economic growth, none of the individual variables is statistically significant at $5 \%$ level. However, these variables are jointly significant in explaining economic growth. There is no problem of multi-collinearity in this model.

The fourth model (Model $4 \mathrm{~A}$ ) incorporates the two economic variables reflecting monetary and fiscal policy, both of the financial variables, and two accounting variables. The accounting variables in this case are voice and accountability as a representative governance indicator, and accounting and financial graduates' expertise as a representative of accounting and finance indicator. It can be seen that the variables are jointly significant in explaining the variation in economic growth, with government final consumption expenditure, money supply, final direct investment and accounting and financial graduates' expertise being statistically significant among the individual independent variables. It can be seen that incorporating the selected economic, accounting and financial variables in the fourth model explain the variation in economic growth more accurately (at $60.7 \%$ ), compared to using only the economic variables in the second model (which was $23.7 \%$ ).

Since the variable regulatory quality does not have significant effect on GDP, we have removed it and carried out regression again (Model $4 \mathrm{~B}$ ). The variables now have more significant effect on GDP. The overall joint effect of Model-4B remains almost the same as that of Model-4A.

Clearly, the models $3,4 \mathrm{~A}$ and $4 \mathrm{~B}$ indicate that integration of financial and accounting variables with economic variables has a more significant effect on explaining economic growth than economic variables alone. 
Table-1: The Proposed Models and their Effect on Economic Growth

\begin{tabular}{|c|c|c|c|}
\hline Models & Variables Included & Purpose & Impact on Economic Growth \\
\hline $\begin{array}{l}\text { Model-1: } \\
\Delta G D P_{t}=f\left(\Delta C_{t}, \Delta I_{t}\right. \\
\left.\Delta G_{t}, \Delta N X_{t}, \Delta M S_{t}\right)\end{array}$ & $\begin{array}{l}\text { It includes the variables used in } \\
\text { conventional macroeconomic models. } \\
\text { These are: Gross Domestic Product (GDP), } \\
\text { Household final consumption expenditure } \\
\text { (C), Gross capital formation (I), General } \\
\text { government final consumption expenditure } \\
\text { (G), Net exports of goods and services } \\
\text { (NX) and Money Supply (MS). }\end{array}$ & $\begin{array}{l}\text { To examine the impact of } \\
\text { economic variables on } \\
\text { economic growth. }\end{array}$ & $\begin{array}{l}\text { The five economic variables } \\
\text { account for } 48.5 \% \text { variation } \\
\text { in economic growth. } \\
\text { Statistically significant at } 5 \% \\
\text { level }\end{array}$ \\
\hline $\begin{array}{l}\text { Model-2: } \\
\Delta G D P_{t}=f\left(\Delta G_{t}, \Delta I_{t}\right)\end{array}$ & $\begin{array}{l}\text { It includes only changes in government } \\
\text { final consumption expenditure }(G) \text { and } \\
\text { Gross capital formation (I), the two variables } \\
\text { representing the private sector. }\end{array}$ & $\begin{array}{l}\text { To modify Model-1, by } \\
\text { omitting statistically } \\
\text { insignificant variables, and } \\
\text { leaving only consumption } \\
\text { and investment as the } \\
\text { explanatory variables to } \\
\text { see whether the } \\
\text { insignificant variables in } \\
\text { model } 1 \text { become significant } \\
\text { when taken separately. }\end{array}$ & $\begin{array}{l}\text { The two economic variables } \\
\text { account for } 23.7 \% \text { variation } \\
\text { in economic growth. } \\
\text { Statistically significant at } 5 \% \\
\text { level }\end{array}$ \\
\hline $\begin{array}{l}\text { Model-3: } \\
\Delta G D P_{t}=f\left(\Delta C_{t}, \Delta_{t}, \Delta G_{t}\right. \\
\Delta N X_{t}, \Delta M S_{t}, \Delta F D L_{t} \\
\Delta S T_{t}, \Delta C C_{t}, \Delta R Q_{t} \\
\left.\Delta V A_{t}, \Delta C D_{t}, \Delta A F_{t}\right)\end{array}$ & $\begin{array}{l}\text { It includes all the economic variables } \\
\text { namely, Household final consumption } \\
\text { expenditure (C), Gross capital formation (I), } \\
\text { General government final consumption } \\
\text { expenditure (G), Net exports of goods and } \\
\text { services (NX) and Money supply (MS), as } \\
\text { well as the financial variables namely, } \\
\text { Foreign direct investment (FDI) and Stock } \\
\text { Traded (ST), and accounting variables } \\
\text { namely, Control of Corruption (CC), } \\
\text { Regulatory quality (RQ), Voice and } \\
\text { Accountability (VA), Carbon dioxide } \\
\text { emissions (CD), and Accounting and } \\
\text { Finance graduates' expertise (AF). }\end{array}$ & $\begin{array}{l}\text { To examine the impact of } \\
\text { economic, financial and } \\
\text { accounting variables on } \\
\text { economic growth. }\end{array}$ & $\begin{array}{l}\text { The twelve economic, } \\
\text { financial and accounting } \\
\text { variables account for } 65.7 \% \\
\text { variation in economic growth, } \\
\text { and all the variables and the } \\
\text { model as a whole are } \\
\text { statistically insignificant. } \\
\text { Statistically significant at 5\% } \\
\text { level }\end{array}$ \\
\hline $\begin{array}{l}\text { Model-4A: } \\
\Delta G D P_{t}=f\left(\Delta G_{t}, \Delta M S_{t},\right. \\
\Delta F D I_{t}, \Delta S T_{t} \\
\left.\Delta R Q_{t}, \Delta A F_{t}\right)\end{array}$ & $\begin{array}{l}\text { It includes private sector economic variables, } \\
\text { the financial variables, and selected } \\
\text { accounting variables. General government } \\
\text { final consumption expenditure (G), Money } \\
\text { supply (MS), Foreign direct investment } \\
\text { (FDI), Stock traded (ST), Regulatory quality } \\
\text { (RQ), and Accounting and Finance } \\
\text { graduates' expertise (AF). }\end{array}$ & $\begin{array}{l}\text { To modify Model-3, and } \\
\text { include only the economic } \\
\text { variables representing the } \\
\text { private sector, and two } \\
\text { most statistically significant } \\
\text { variables? each from } \\
\text { among the financial and } \\
\text { accounting variables. Here } \\
\text { CD has been omitted, } \\
\text { because it was insignificant. }\end{array}$ & $\begin{array}{l}\text { The six economic, financial } \\
\text { and accounting variables } \\
\text { account for } 60.7 \% \text { variation } \\
\text { in economic growth. } \\
\text { Statistically significant at } 5 \% \\
\text { level }\end{array}$ \\
\hline $\begin{array}{l}\text { Model-4B: } \\
\Delta G D P_{t}=f\left(\Delta G_{t}, \Delta M S_{t}\right. \\
\left.\Delta F D I_{t}, \Delta S T_{t}, \Delta A F_{t}\right)\end{array}$ & $\begin{array}{l}\text { It includes General government final } \\
\text { consumption expenditure (G), Money supply } \\
\text { (MS), Foreign direct investment (FDI), and } \\
\text { Stock Traded (ST) and Accounting and } \\
\text { Finance graduates'expertise (AF). }\end{array}$ & $\begin{array}{l}\text { To modify Model-4A and } \\
\text { in clude signific ant } \\
\text { variables of Model-4A only. } \\
\text { Model } 4 \mathrm{~B} \text { is almost same } \\
\text { as Model- } 4 \mathrm{~A} \text {. In this } \\
\text { Model-4B also, CD has } \\
\text { been omitted because it } \\
\text { was not significant. }\end{array}$ & $\begin{array}{l}\text { The five economic, financial } \\
\text { and a c c o u n t i n g } \\
\text { variables account for } 60.6 \% \\
\text { variation in economic growth. } \\
\text { Statistically significant at 5\% } \\
\text { level }\end{array}$ \\
\hline
\end{tabular}

The table shows that Model- 1 better explains the impact on economic growth, compared to Model-2. It can also be seen in this table that Model-4A and Model-4B better explain the impact on economic growth than Model-1 and Model-2 which have used economic variables only. The table further shows that Model-3, Model-4A and Model-4B better explain the impact on economic growth in comparison to Model-2, thereby showing that a model that includes economic, financial and accounting variables better explains economic growth in comparison to a model that has economic variables only. 


\section{Limitations and Conclusion}

It can be seen in the foregoing that a major limitation of the study is the omission of some of the variables in the regression analysis, largely due to the unavailability of data, particularly of accounting variables. These variables would have undoubtedly enriched the study. Once such variable could have been the Environmental Sustainability Index (ESI), a composite index covering natural resource endowment, past and present pollution levels, environmental management efforts, contributions to protection of the global commons, and a society's capacity to improve its environmental performance over time. The ESI would have indubitably accounted for the cost of degradation as well as the costs of sustaining the environment. Another accounting variable that would have been useful as an accounting variable is the Human Development Index (HDI), which takes into account three dimensions pertinent to human development: life expectancy, access to knowledge and standard of living. Unfortunately, the conceptualization and the measurement of both the ESI and the HDI have been fairly recent, as a result of which there is insufficient data, particularly in the context of Bangladesh. The variables that could not be included were subject to different feasibility constraints. Since the data of ideal accounting variables were rarely found, adequate care might not have been taken to look into whether the accounting variables would have a short-run impact on economic growth or not. It was felt that just the possible long-run impact of the accounting variables on economic growth might serve the purpose of the models developed over here. Besides, experts belonging to different intellectual disciplines attested the details included in the models as acceptable. It is likely to be appreciated that the accounting variables included in the models, though not ideal, are indicative enough. The future researchers are expected to bridge the research void lying in the present context of the study.

It may be observed that the complete details covering all the variables pertaining to Economics, Finance and Accounting were more or less available for the period from 1980 to 2009. The data for thirty years were available in somewhat organized form, although for some years data had to be estimated. Furthermore, it deserves mention that the data belonging to the earlier period could not be accessed due to the fact that measurements of the governance indicators were not found. The time series data spanning 30 years may be considered adequate for statistical analysis meant for explaining the dependent variable.

It is evident from the study (reflected in Table \# 1) that Model-1 better explains the impact on economic growth, compared to Model-2. It is also evident that Model-4A and Model-4B better explain the impact on economic growth than Model-1 and Model-2 which have used economic variables only. The table further indicates that Model-3, Model-4A and Model-4B better explain the impact on economic growth in comparison to Model-2, thereby showing that a model that includes economic, financial and accounting variables better explains economic growth in comparison to a model that has economic variables only. It results from the analysis of the developed models that Model-3, Model$4 \mathrm{~A}$ and Model-4B comprising economic, financial and accounting variables might work as an efficient instrument in the hands of economic policy makers, who are used to applying the models like Model-1 and Model-2 (both consisting of only economic variables) for the purpose of explaining the impact on economic growth. 
The combination of the three seasoned intellectual disciplines has several acceptable consequences, namely, (a) there would be a positive synergy effect; (b) churning the finer issues in each of these disciplines would benefit the economic policy makers in ways more than one in the sense that they would be in a position to hone their skills in selecting the likeable alternatives from which selection of the most acceptable ones could be made; (c) the simple adage of "Unity is Strength" would show up in making the policy makers more knowledgeable regarding the alternatives available, analysis of the alternatives ; and (d) finally, the most acceptable alternative could be selected from the array of alternatives, taking into view the feasibility and other constraints.

It may be underlined that selected economic, financial and accounting variables can jointly explain economic growth more accurately than by using economic variables alone. This study, especially in Bangladesh, probably treads into an un-trodden area of scanning the collective impact of economic, financial and accounting variables on economic growth. In future studies, it may be possible to refine the model to better explain the individual and collective impact of these variables on economic growth. By studying these impacts, it can even be possible for various economic policies to be formulated in order to promote economic growth and reduce poverty on realistic grounds. It may thus be concluded by reiterating and confirming the hypothesis that the integration of all the three types of variables concerning Economics, Finance and Accounting is more effective than taking only economic variables in explaining the economic growth rate of a nation. 


\section{References}

Agrawalla, R. K., \& Tuteja, S. K. 2007, 'Causality between stock market development and economic growth: A case study of India,' Journal of Management Research, Vol. 7, No. 3, pp. 158-168.

Athukorala, P. 2003, 'The Impacts of Foreign Direct Investment and Economic Growth: A Case Study in Sri Lanka,' Achievements and Policy Option in W.D. Lakshman (ed.) Dilemmas of Development, Sri Lanka Association of Economists, Colombo, pp. 386-421.

Balamurali, N., \& Bogahawatte, C. 2004, 'Foreign Direct Investment and Economic Growth in Sri Lanka,' Sri Lankan Journal of Agricultural Economics, Vol. 6, No. 1, pp. 37-50.

Colombage, S. S. 1992, 'A macroeconometric model for Sri Lanka,' in S. N. H. Naqvi \& S. B. Samad (ed.), SAARC LINK: An Econometric Approach, New Delhi; Oxford \& IBH Publishing Company. pp. 127-148.

Desai, M. J. 1973, 'Macro Econometric Models for India: A Survey', Sankhya; reprinted in Survey of Research in Economics, Vol. 7, Econometrics (1978), Indian Council of Social Sciences Research, Allied Publishers, New Delhi.

Enthoven, A. J. H., Mitwalhi B. A., Robert D., C. L. Mitchell, Ricardo M. Mora and Norlin G. Rueschhoff 1978, Accounting Education and the Third World, American Accounting Association, Sarasota.

Enthoven, Adolf J. H. 1982, Accounting Education: Its Importance and Requirements, Center for International Accounting Development, the University of Texas, Dallas.

Espinoza, R., Fornari, F. \& Lombardi, M. J. 2009, 'The Role of Financial Variables in Predicting Economic Activity,' European Central Bank Working Paper Series No. 1108.

Fink, G., Haiss, P. \& Hristoforova, S. 2003, 'Bond Markets and Economic Growth,' IEF Working Paper No. 49.

Gujarati, D. N. 2003, Basic Econometrics, McGraw-Hill, New York.

Haque, N. U., Lahiri, K., \& Montiel, P. J. 1990, 'A Macroeconometric Model for Developing Countries,' Staff Papers - International Monetary Fund, Vol. 37, No. 3, pp. 537-559.

Harvey, C. R. 1989, 'Forecasts of Economic Growth from the Bond and Stock Markets,' Financial Analysts Journal, September/October, pp. 38-45.

Hosmer, D. W. Lemeshow S. 2000, Applied Logistic Regression, John Wiley \& Sons, Inc., New York.

Hossain, M. I. \& Razzaque, A. 2003, 'A Macroeconometric Model of Bangladesh: Specification and Estimation,' Micro Impacts of Macroeconomic and Adjustment Policies in Bangladesh (MIMAP-Bangladesh), Technical Paper No. 6.

\begin{tabular}{llll|l}
\hline Journal of Independent Studies and Research - MSSE & Volume 10 & Number 1 & January 2012 & 137
\end{tabular} 
Hossain, M. I. \& Razzaque, A. 2003, 'A Macroeconometric Model of Bangladesh: Specification and Estimation,' Micro Impacts of Macroeconomic and Adjustment Policies in Bangladesh (MIMAP-Bangladesh), Technical Paper No. 6.

Husain, F., \& Mahmood, T. 2001, 'The Stock Market and the Economy in Pakistan,' The Pakistan Development Review, Vol. 40, No. 2, pp. 107-114.

Iqbal, Z., \& Zahid, G. M. 1998, 'Macroeconomic Determinants of Economic Growth in Pakistan,' The Pakistan Development Review, Vol. 37, No. 2, pp. 125-148.

Jadhav, N. 1990, 'Monetary Modelling of the Indian Economy: A Survey', Reserve Bank of India, Occasional Papers, Vol. 11, No. 2.

Kaufmann, D., Kraay, A. \& Mastruzzi, M. 2010, 'The Worldwide Governance Indicators: Methodology and Analytical Issues,' World Bank Policy Research Working Paper No. 5430.

Kazmi, A. A. 1992, 'Ricardian Equivalence: Some Macro-econometric Tests for Pakistan', The Pakistan Development Review, Vol. 31, No. 4, pp. 743-758.

Khan, M. A., \& Din M. U. 2011, 'A Dynamic Macroeconometric Model of Pakistan's Economy,' Pakistan Institute of Development Economics Working Paper No. 2011:69.

Krishnamurty, K. 2002, 'Macroeconometric Models for India: Past, Present and Prospects,' Economic and Political Weekly, Vol. 37, No. 42, pp. 4295-4308.

Kwon, C. S., \& Shin, T.S. 1999, 'Co-integration and causality between macroeconomic variables and stock market returns,' Global Finance Journal, Vol. 10, pp. 71-81.

Mallick, S. K. 2004, 'A Dynamic Macroeconometric Model for Short-Run Stabilization in India,' Applied Economics, Vol. 36, No. 3, pp. 261-76.

Maosheng, R., \& Weiguo, Z. 2002, 'An Empirical Analysis on the Connection between China's Stock Market and Economic Growth,' Journal of Chongqing University, Vol. 25, No. 11, pp. 12-15.

Maroney, N., Hassan, M. K., Basher, S. A., \& Isik, I. 2004, 'A macroeconometric model of the Bangladesh economy and its policy implications,' Journal of Developing Areas, 2004, Vol. 38, No. 1, pp. 135-49.

Mc Quarrie, Allan D. R. and Chih-ling Tsai 1998, Regression and Time Series Model Selection, World Scientific Publishing Company, New Jersey.

Naqvi, S. N. H., Khan, A. H., Khilji, N. M., \& Ahmed, A. M. 1983, The PIDE Macroeconometric Model of Pakistan's Economy, Pakistan Institute of Development Economics, Islamabad.

Padhan, P. C. 2007, 'The nexus between stock market and economic activity: an empirical analysis for India,' International Journal of Social Economics, Vol. 34, No. 10, pp. 741-753.

\begin{tabular}{l|lll}
\hline 138 & January $2012 \quad$ Volume 10 & Number $1 \quad$ Journal of Independent Studies and Research - MSSE
\end{tabular}


Pani, P. K. 1984, 'A Macro Model of Indian Economy with Special Reference to Output, Demand and Prices (1969-70 to 1981-82),' Reserve Bank of India, Occasional Papers, Vol. 5, No. 2.

Parikh, A. 1983, 'Construction of a Macroeconomic Model of the Bangladesh Economy,' Bangladesh Development Studies, Vol. 11, No. 4, pp. 1-16.

Parry, M. and Khan F. 1984, A Survey of Published Accounts of Bangladesh, The Institute of Chartered Accountants of Bangladesh, Dhaka and The United Nations Department of Technical Co-operation for Development.

Ra, S., and Rhee, C. Y. 2005, 'Nepal Macroeconometric Model,' Asian Development Bank, Working Paper Series No. 1.

Rahman, S. H., \& Shilpi, F. J. 1996, 'A Macroeconometric Model of the Bangladesh Economy: Model, Estimation, Validation and Policy Simulation,' Research Monograph no. 17, Bangladesh Institute of Development Studies, pp. 1-88.

Rashid, M. A. 1981, 'A Macro-econometric Model of Bangladesh,' Bangladesh Development Studies, Vol. 9, No. 3, pp. 21-44.

Rudebusch, G. D., \& Williams, J. C. 2008, 'Forecasting Recessions: The Puzzle of the Enduring Power of the Yield Curve,' Federal Reserve Bank of San Francisco Working Paper Series No. 2007-16.

Sapkota, P. R., \& Sharma, R. K. 1998, 'Computable General Equilibrium Model of Nepalese Economy,' Working paper, Micro Impact of Macroeconomic and Adjustment Policies (MIMAP), Third annual Meeting, Nepal.

Schultz, J. Josep, Jr. (ed.) 1989, 'Reorienting Accounting Education: Reports on The Environment Professoriate and Curriculum of Accounting,' Accounting Education Series Vol. 10, American Accounting Association, Sarasota.

Shimul, S. N., Abdullah, S. M., \& Siddiqua, S. 2009, 'An examination of FDI and growth nexus in Bangladesh: Engle Granger and bound testing cointegration approach,' BRAC University Journal, Vol. 6, No. 1, pp. 69-76.

Shourie, A. 1972, 'The Use of Macro-Economic Regression Models of Developing Countries for Forecasts and Policy Prescription: Some Reflections on Current Practice,' Oxford Economic Papers, Vol. 24, No. 1, pp. 1-35.

Stock, J. H., \& Watson, M. W. 2003, 'Forecasting output and inflation: the role of asset prices,' Journal of Economic Literature, Vol. 41, pp. 788-829.

Valadkhani, A. 2005, 'Macroeconometric Modelling: Approaches and Experiences in Developing Countries,' Applied Econometrics and International Development, Vol. 5, No. 1 , pp. 5-24.

Williams, D. Z. 1991, 'The Challenge of Change in Accounting Education,' Issues in Accounting Education (Spring), pp. 126-133.

World Bank, Global Development Finance, various years.

World Bank, World Development Indicators, various years.

\begin{tabular}{llll|l}
\hline Journal of Independent Studies and Research - MSSE & Volume 10 & Number 1 & January 2012 & 139
\end{tabular} 


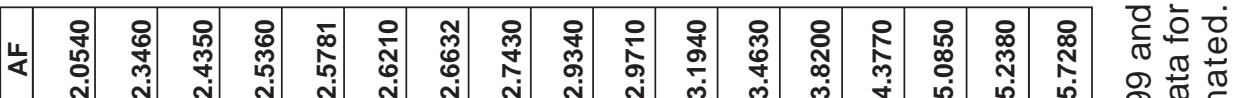

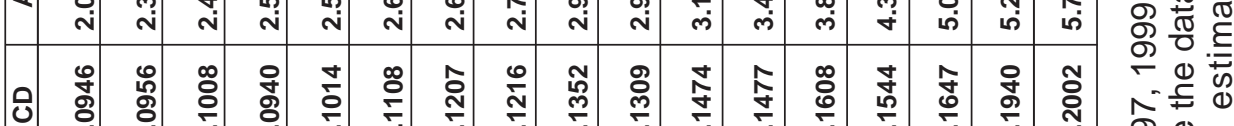

赵

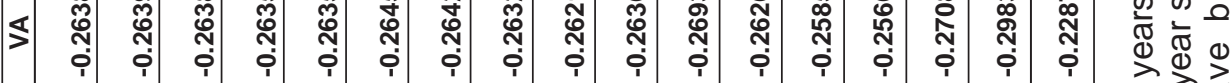

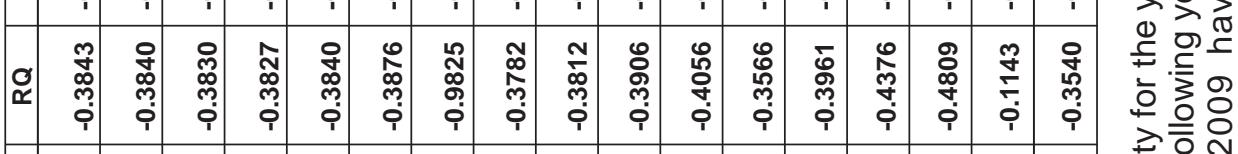

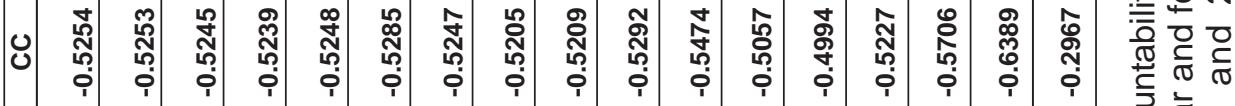

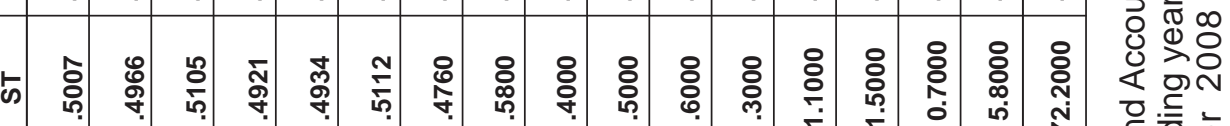

을

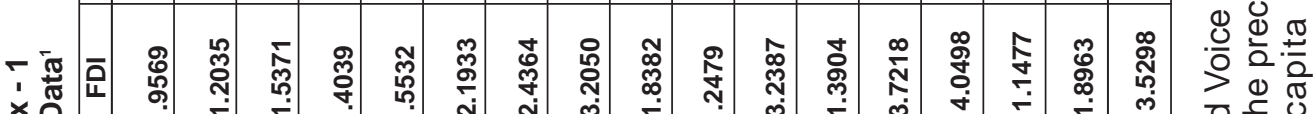

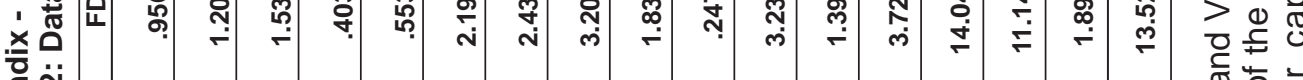

0 ป $\$ ป

$\sum$ ๖

\% $\infty$ o

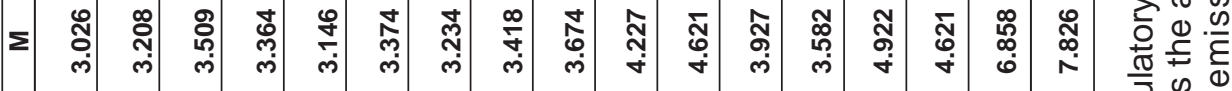

× \begin{tabular}{l}
$\hat{f}$ \\
\hline
\end{tabular}

ง

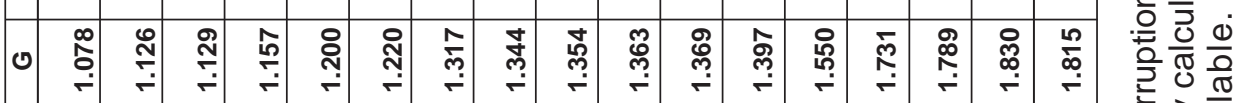

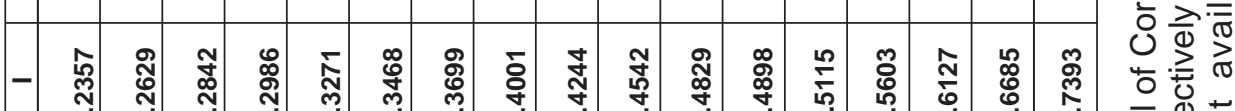

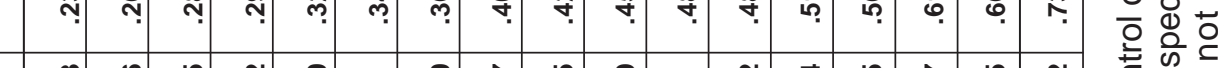

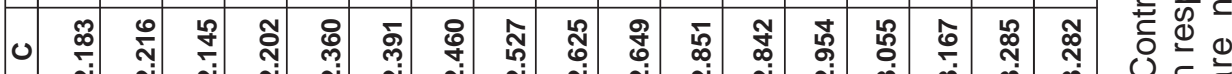

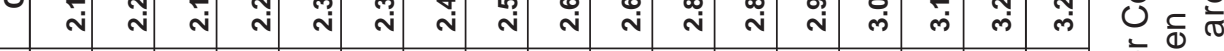

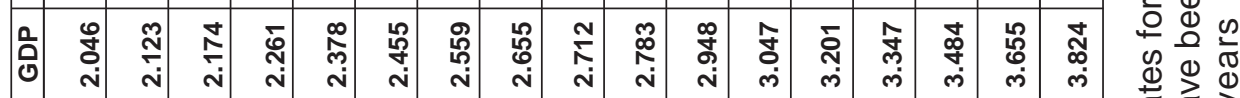

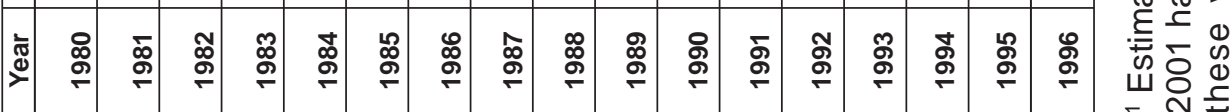

$140 \quad$ January $2012 \quad$ Volume $10 \quad$ Number $1 \quad$ Journal of Independent Studies and Research - MSSE 


\begin{tabular}{|c|c|c|c|c|c|c|c|c|c|c|c|c|c|}
\hline 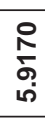 & $\begin{array}{l}0 \\
0 \\
0 \\
0 \\
0\end{array}$ & 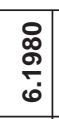 & 号 & 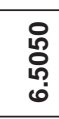 & 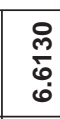 & 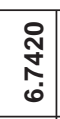 & 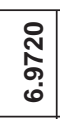 & $\stackrel{\infty}{\stackrel{\infty}{\Gamma}}$ & $\underset{\substack{0\\
}}{ }$ & $\mid \begin{array}{l}R \\
\frac{R}{j} \\
\end{array}$ & مी & 怘 & $\begin{array}{l}0 \\
0 \\
0\end{array}$ \\
\hline 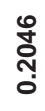 & 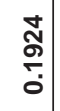 & $\begin{array}{l}\bar{\infty} \\
\stackrel{\circ}{0} \\
\overline{0}\end{array}$ & 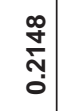 & $\begin{array}{l}\text { \ุ } \\
\text { d̦ }\end{array}$ & $\begin{array}{l}\text { 今్ } \\
\text { స్ } \\
\text { d }\end{array}$ & 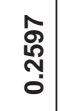 & $\begin{array}{c}\mathfrak{n} \\
\stackrel{0}{0} \\
0\end{array}$ & 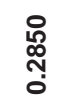 & స్ స్ & 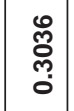 & 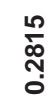 & 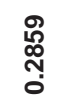 & 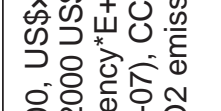 \\
\hline $\begin{array}{l}\stackrel{0}{0} \\
\text { ָ̦ } \\
\text { i }\end{array}$ & 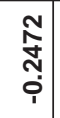 & 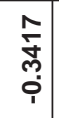 & 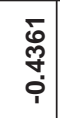 & 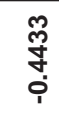 & $\begin{array}{l}\text { पे } \\
\text { ధุ } \\
\text { †े }\end{array}$ & 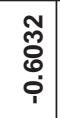 & $\begin{array}{l}0 \\
0 \\
0 \\
0 \\
0 \\
i\end{array}$ & 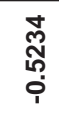 & \begin{tabular}{l}
0 \\
0 \\
\multirow{f}{*}{} \\
0 \\
0
\end{tabular} & 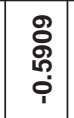 & 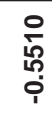 & 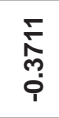 & O \\
\hline 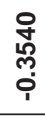 & $\begin{array}{l}0 \\
0 \\
0 \\
0 \\
i \\
i \\
\end{array}$ & 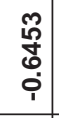 & $\begin{array}{l}\overline{0} \\
\mathbf{8} \\
0 \\
i \\
\end{array}$ & 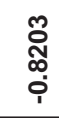 & 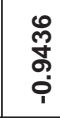 & $\begin{array}{l}0 \\
\text { L } \\
0 \\
0 \\
0 \\
\end{array}$ & 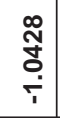 & $\begin{array}{l}\stackrel{0}{\circ} \\
\stackrel{\circ}{+} \\
\stackrel{0}{0}\end{array}$ & $\begin{array}{l}\hat{0} \\
\$ \\
\infty \\
i\end{array}$ & 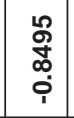 & $\begin{array}{l}9 \\
0 \\
0 \\
0 \\
i\end{array}$ & $\begin{array}{l}\stackrel{8}{0} \\
\stackrel{0}{0} \\
0 \\
i\end{array}$ & \\
\hline $\begin{array}{l}\text { : } \\
\text { ț. } \\
\text { i. }\end{array}$ & $\begin{array}{l}\mathscr{0} \\
0 \\
0 \\
\vdots \\
\vdots\end{array}$ & 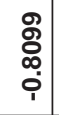 & 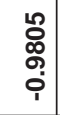 & 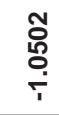 & $\frac{8}{\frac{8}{7}}$ & 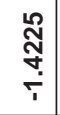 & 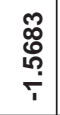 & 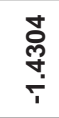 & 草 & 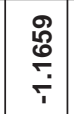 & 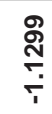 & 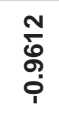 & \\
\hline 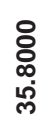 & 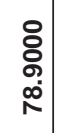 & 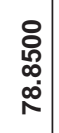 & $\begin{array}{l}0 \\
\stackrel{0}{0} \\
\stackrel{0}{0}\end{array}$ & $\begin{array}{l}\frac{O}{C} \\
\frac{1}{+} \\
i\end{array}$ & 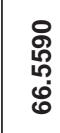 & 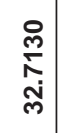 & 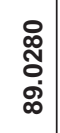 & $\begin{array}{l}\text { ơ } \\
\dot{0} \\
\dot{0}\end{array}$ & $\begin{array}{l}\text { त్ } \\
\text { 广্ల }\end{array}$ & 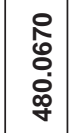 & 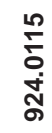 & $\begin{array}{l}\hat{5} \\
\stackrel{5}{0} \\
\dot{0} \\
\dot{0}\end{array}$ & \\
\hline 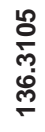 & 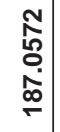 & $\begin{array}{l}0 \\
0 \\
0 \\
0 \\
0 \\
\end{array}$ & 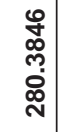 & 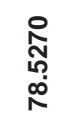 & 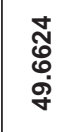 & 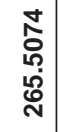 & 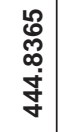 & 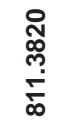 & 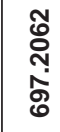 & 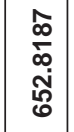 & 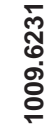 & 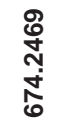 & \\
\hline $\begin{array}{l}\text { gे } \\
\text { ف }\end{array}$ & $\begin{array}{l}R \\
\stackrel{R}{0} \\
\dot{0}\end{array}$ & 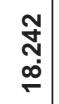 & $\begin{array}{l}\stackrel{0}{0} \\
\dot{\sim} \\
\dot{\sim}\end{array}$ & $\begin{array}{l}\stackrel{9}{9} \\
\infty \\
\stackrel{j}{j}\end{array}$ & 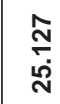 & $\begin{array}{l}\stackrel{\circ}{g} \\
\dot{\leftrightarrow} \\
\dot{\leftrightarrow}\end{array}$ & 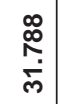 & 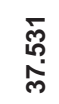 & 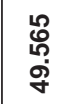 & 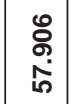 & $\begin{array}{l}\text { 윰 } \\
\dot{0}\end{array}$ & $\begin{array}{l}\bar{\delta} \\
\dot{0} \\
\dot{T}\end{array}$ & \\
\hline : & 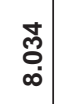 & 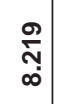 & $\begin{array}{l}: \\
\vdots \\
\dot{\sigma}\end{array}$ & 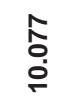 & 赵 & 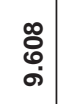 & $\begin{array}{l}\hat{\tilde{o}} \\
\stackrel{0}{0}\end{array}$ & : & 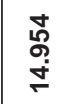 & 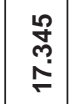 & $\begin{array}{l}\infty \\
\stackrel{\infty}{0} \\
\stackrel{\leftrightarrow}{0}\end{array}$ & 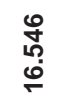 & \\
\hline స్. & 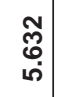 & $\frac{8}{6}$ & $\begin{array}{c}\infty \\
\infty \\
: \\
0 \\
0\end{array}$ & مُ & $\stackrel{\circ}{\stackrel{\circ}{\sim}}$ & $\begin{array}{l}\text { S̆ } \\
\stackrel{\leftrightarrow}{\wedge}\end{array}$ & 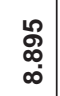 & 芯 & 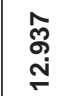 & $\begin{array}{l}\hat{\vdots} \\
\dot{\tau}\end{array}$ & $\begin{array}{l}\stackrel{0}{0} \\
\stackrel{0}{\circ}\end{array}$ & 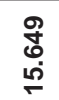 & \\
\hline 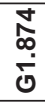 & $\frac{\mathfrak{N}}{\mathrm{N}}$ & 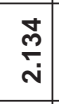 & $\underset{\substack{5 \\
\mathrm{in}}}{\mathrm{in}}$ & ฌั & "̄o & $\begin{array}{l}0 \\
0 \\
0 \\
\dot{m} \\
\end{array}$ & 总 & స్్ָ & 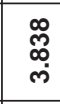 & 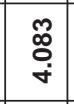 & ্ָণ্ণ & 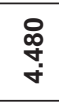 & \\
\hline 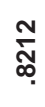 & ֻัญ & $\stackrel{m}{\stackrel{m}{0}}$ & 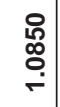 & 宪 & $\underset{\substack{\text { Tे }\\
}}{ }$ & 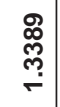 & 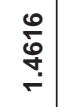 & 递 & 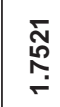 & 茴 & 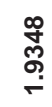 & 㝵 & \\
\hline 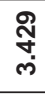 & $\begin{array}{l}: \\
\vdots \\
\grave{n} \\
\end{array}$ & 을 & 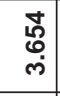 & $\underset{\substack{\infty \\
\infty}}{N}$ & & 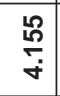 & 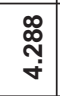 & 草 & 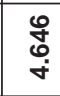 & 产 & $\frac{\mathscr{\Phi}}{i \sigma}$ & 字 & \\
\hline 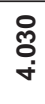 & ז্ডে & 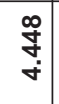 & $\begin{array}{l}\mathbf{N} \\
\mathbf{T} \\
\dot{T}\end{array}$ & ষ্ণ্ণে & $\frac{\infty}{\omega^{\circ}}$ & 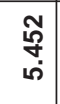 & 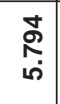 & $\frac{\stackrel{0}{0}}{0}$ & 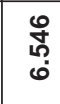 & $\begin{array}{l}\hat{\grave{o}} \\
\dot{0} \\
\dot{0}\end{array}$ & 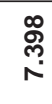 & 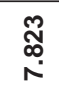 & \\
\hline ఏ్ & 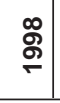 & 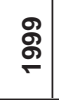 & రి & ర్ & ఫิ & ర్̊ి & ठ̀े & ֻั & : & స్ & : ڤ్ & రి & 耑吕兰 \\
\hline
\end{tabular}




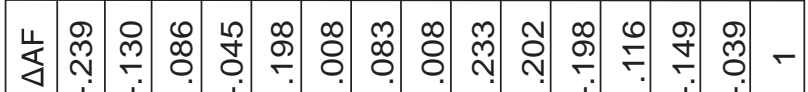

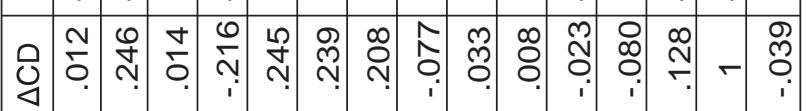

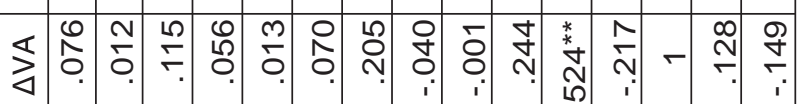

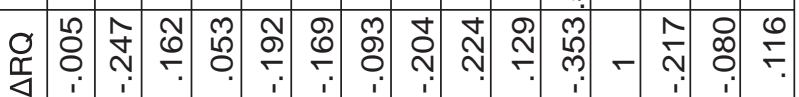

نุ

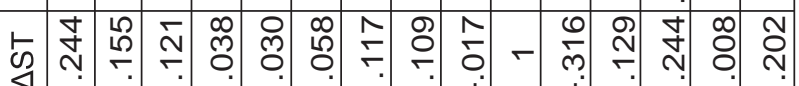

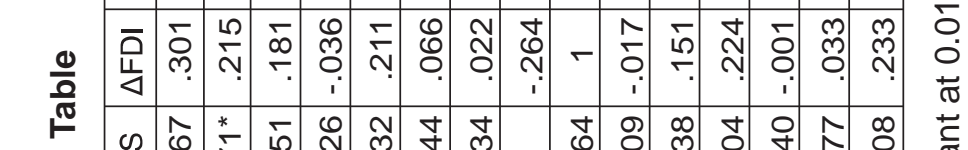

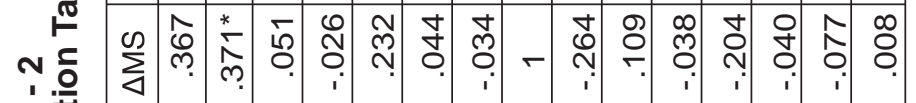

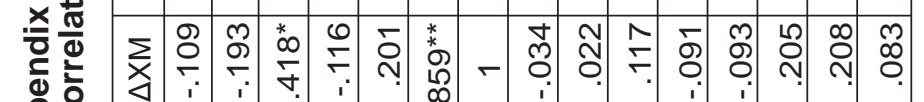

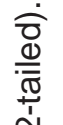

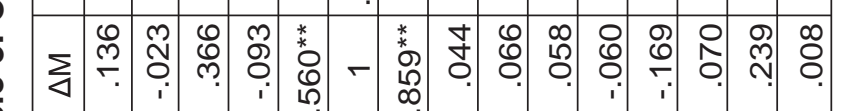

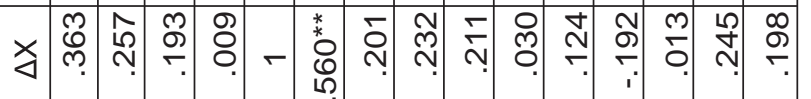

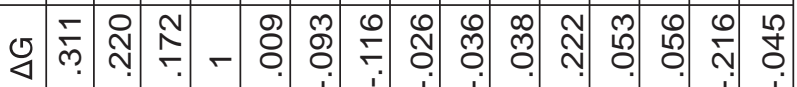

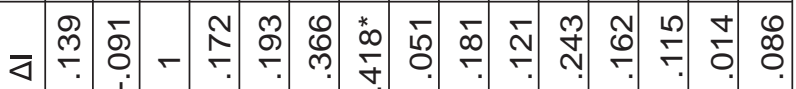

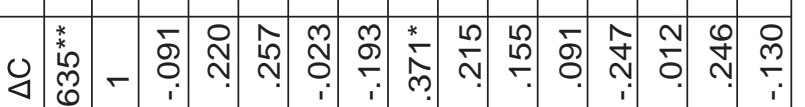

产

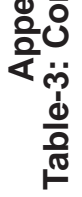

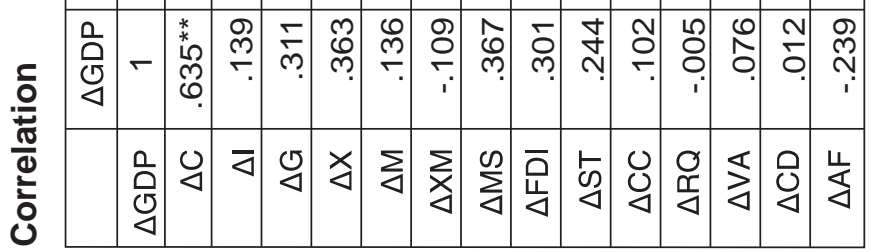




\section{Appendix-3:}

\section{Models}

Model-1:

$\Delta \mathrm{GDP}_{\mathrm{t}}=0.0266+0.289 \Delta \mathrm{C}+0.0828 \Delta \mathrm{l}+0.0395 \Delta \mathrm{G}-0.00204 \Delta \mathrm{NX}+0.0216 \Delta \mathrm{MS}$ $\begin{array}{lllll}p \text {-values } \rightarrow & (0.004) & (0.316) & (0.337) & (0.756)\end{array}$

$R^{2}=0.485, F=4.330, p$-value $=0.006$, Adjusted $R$ Square $=0.373$.

\section{Model Summary}

\begin{tabular}{|c|c|c|c|}
\hline $\mathrm{R}$ & $\mathrm{R}$ Square & $\begin{array}{c}\text { Adjusted } \\
\text { R Square }\end{array}$ & $\begin{array}{c}\text { Std. Error } \\
\text { of the } \\
\text { Estimate }\end{array}$ \\
\hline .696 & .485 & .373 & .0097052 \\
\hline
\end{tabular}

a. Predictors: (Constant), $\Delta \mathrm{MS}, \Delta \mathrm{G}, \Delta \mathrm{NX}, \Delta \mathrm{C}, \Delta \mathrm{l}$

\section{ANOVA}

\begin{tabular}{|c|c|c|c|c|c|}
\hline & $\begin{array}{c}\text { Sum of } \\
\text { Squares }\end{array}$ & $\mathrm{df}$ & $\begin{array}{c}\text { Mean } \\
\text { Square }\end{array}$ & $\mathrm{F}$ & Sig. \\
\hline Regression & .002 & 5 & .000 & 4.330 & .006 \\
\hline Residual & .002 & 23 & .000 & & \\
\hline Total & .004 & 28 & & & \\
\hline
\end{tabular}

a. Predictors: (Constant), $\Delta \mathrm{MS}, \Delta \mathrm{G}, \Delta \mathrm{NX}, \Delta \mathrm{C}, \Delta \mathrm{l}$

b. Dependent Variable: $\triangle \mathrm{GDP}$

\section{Coefficients}

\begin{tabular}{|c|c|c|c|c|c|}
\hline & $\begin{array}{c}\text { Unstandardized } \\
\text { Coefficients }\end{array}$ & & $\begin{array}{c}\text { Standardized } \\
\text { Coefficients }\end{array}$ & $\mathrm{t}$ & Sig. \\
\hline & $\mathrm{B}$ & $\begin{array}{c}\text { Std. } \\
\text { Error }\end{array}$ & Beta & & \\
\hline (Constant) & $2.657 \mathrm{E}-02$ & .007 & & 3.802 & .001 \\
\hline$\Delta \mathrm{C}$ & .289 & .090 & .548 & 3.229 & .004 \\
\hline$\Delta \mathrm{I}$ & $8.280 \mathrm{E}-02$ & .081 & .176 & 1.024 & .316 \\
\hline$\Delta \mathrm{G}$ & $3.952 \mathrm{E}-02$ & .040 & .158 & .981 & .337 \\
\hline$\Delta \mathrm{NX}$ & $-2.040 \mathrm{E}-03$ & .006 & -.054 & -.315 & .756 \\
\hline$\Delta \mathrm{MS}$ & $2.161 \mathrm{E}-02$ & .023 & .157 & .957 & .348 \\
\hline
\end{tabular}

a. Dependent Variable: $\triangle \mathrm{GDP}$

The Model- 1 is statistically significant at $5 \%$ level.

$P$-value $<0.05$ means significant else not significant. 


\section{Model-2:}

$$
\begin{aligned}
& \Delta \mathrm{GDP}_{\mathrm{t}}=0.0362+0.0804 \Delta \mathrm{G}+0.0518 \Delta \mathrm{MS} \\
& \mathrm{p} \text {-values } \rightarrow \quad(0.043) \quad(0.024) \\
& \quad R^{2}=0.237, F=4.038, p \text {-value }=0.030, \text { Adjusted } \mathrm{R} \text { Square }=0.178 .
\end{aligned}
$$

\section{Model Summary}

\begin{tabular}{|c|c|c|c|}
\hline $\mathrm{R}$ & $\mathrm{R}$ Square & $\begin{array}{c}\text { Adjusted } \mathrm{R} \\
\text { Square }\end{array}$ & $\begin{array}{c}\text { Std. Error of the } \\
\text { Estimate }\end{array}$ \\
\hline .487 & .237 & .178 & .0111090 \\
\hline
\end{tabular}

a. Predictors: (Constant), $\Delta \mathrm{MS}, \Delta \mathrm{G}$

\section{ANOVA}

\begin{tabular}{|c|c|c|c|c|c|}
\hline & $\begin{array}{c}\text { Sum of } \\
\text { Squares }\end{array}$ & Df & $\begin{array}{c}\text { Mean } \\
\text { Square }\end{array}$ & $\mathrm{F}$ & Sig. \\
\hline Regression & .001 & 2 & .000 & 4.038 & .030 \\
\hline Residual & .003 & 26 & .000 & & \\
\hline Total & .004 & 28 & & & \\
\hline
\end{tabular}

a. Predictors: (Constant), $\Delta \mathrm{MS}, \Delta \mathrm{G}$

b. Dependent Variable: $\triangle \mathrm{GDP}$

Coefficients

\begin{tabular}{|c|c|c|c|c|c|}
\hline & $\begin{array}{c}\text { Unstandardized } \\
\text { Coefficients }\end{array}$ & & $\begin{array}{c}\text { Standardized } \\
\text { Coefficients }\end{array}$ & $\mathrm{t}$ & Sig. \\
\hline & $\mathrm{B}$ & Std. Error & Beta & & \\
\hline (Constant) & $3.619 \mathrm{E}-02$ & .004 & & 8.098 & .000 \\
\hline$\Delta \mathrm{G}$ & $8.036 \mathrm{E}-02$ & .043 & .321 & 1.870 & .073 \\
\hline$\Delta \mathrm{MS}$ & $5.176 \mathrm{E}-02$ & .024 & .375 & 2.188 & .038 \\
\hline
\end{tabular}

a. Dependent Variable: $\triangle$ GDP

The Model- 2 is statistically significant at $5 \%$ level. The reason is that $p$-value is less than 0.05 . 


\section{Model-3:}

$$
\begin{aligned}
& \Delta \mathrm{GDP}_{\mathrm{t}}=0.0329+0.150 \Delta \mathrm{C}+0.0285 \Delta \mathrm{l}+0.0606 \Delta \mathrm{G}-0.00182 \Delta \mathrm{NX}+0.0489 \Delta \mathrm{MS} \\
& \mathrm{p} \text {-values } \rightarrow \quad(0.245) \quad(0.772) \quad(0.194) \quad(0.815) \quad(0.083) \\
& +0.00156 \Delta \mathrm{FDI}+0.00097 \Delta \mathrm{ST}-0.00258 \Delta \mathrm{CC}+0.00032 \Delta \mathrm{RQ}-0.00034 \Delta \mathrm{VA} \\
& \begin{array}{lllll}
(0.056) & (0.315) & (0.887) & (0.945)
\end{array} \\
& +0.00049 \Delta \mathrm{CD}-0.0986 \Delta \mathrm{AF} \\
& \text { (0.989) (0.056) } \\
& R^{2}=0.657, F=2.552, p \text {-value }=0.041, \text { Adjusted } R \text { Square }=0.373 .
\end{aligned}
$$

Model Summary

\begin{tabular}{|c|c|c|c|}
\hline Model & $\mathrm{R}$ & $\mathrm{R}$ Square & $\begin{array}{c}\text { Adjusted } \\
\mathrm{R} \text { Square }\end{array}$ \\
\hline 1 & .696 & .485 & .373 \\
\hline
\end{tabular}

a. Predictors: (Constant), $\Delta \mathrm{MS}, \Delta \mathrm{G}, \Delta \mathrm{NX}, \Delta \mathrm{C}, \Delta \mathrm{I}$

\section{ANOVA}

\begin{tabular}{|c|c|c|c|c|c|c|}
\hline Model & & $\begin{array}{c}\text { Sum of } \\
\text { Squares }\end{array}$ & $\mathrm{df}$ & $\begin{array}{c}\text { Mean } \\
\text { Square }\end{array}$ & $\mathrm{F}$ & Sig. \\
\hline 1 & $\begin{array}{c}\text { Regressio } \\
\mathrm{n}\end{array}$ & .002 & 5 & .000 & 4.330 & .006 \\
\hline & Residual & .002 & 23 & .000 & & \\
\hline & Total & .004 & 28 & & & \\
\hline
\end{tabular}

a. Predictors: (Constant), $\Delta \mathrm{MS}, \Delta \mathrm{G}, \Delta \mathrm{NX}, \Delta \mathrm{C}, \Delta \mathrm{I}$

b. Dependent Variable: $\Delta$ GDP

\section{Coefficients}

\begin{tabular}{|c|c|c|c|c|c|}
\hline & $\begin{array}{c}\text { Unstandardized } \\
\text { Coefficients }\end{array}$ & & $\begin{array}{c}\text { Standardized } \\
\text { Coefficients }\end{array}$ & $\mathrm{t}$ & Sig. \\
\hline & $\mathrm{B}$ & Std. Error & Beta & & \\
\hline (Constant) & $2.657 \mathrm{E}-02$ & .007 & & 3.802 & .001 \\
\hline$\Delta \mathrm{C}$ & .289 & .090 & .548 & 3.229 & .004 \\
\hline$\Delta \mathrm{l}$ & $8.280 \mathrm{E}-02$ & .081 & .176 & 1.024 & .316 \\
\hline$\Delta \mathrm{G}$ & $3.952 \mathrm{E}-02$ & .040 & .158 & .981 & .337 \\
\hline$\Delta \mathrm{NX}$ & $-2.040 \mathrm{E}-03$ & .006 & -.054 & -.315 & .756 \\
\hline$\Delta \mathrm{MS}$ & $2.161 \mathrm{E}-02$ & .023 & .157 & .957 & .348 \\
\hline
\end{tabular}

a. Dependent Variable: $\triangle$ GDP

The Model- 3 is statistically significant at $5 \%$ level. The reason is that $p$-value is less than 0.05 . 


\section{Model-4A:}

$$
\begin{aligned}
& \Delta \mathrm{GDP}_{\mathrm{t}}=0.0367+0.0793 \Delta \mathrm{G}+0.0671 \Delta \mathrm{MS}+0.00204 \Delta \mathrm{FDI}+0.00125 \Delta \mathrm{ST} \\
& \mathrm{p} \text {-values } \rightarrow \quad(0.028) \quad(0.002) \quad(0.001) \quad(0.060) \\
& -0.00079 \Delta \mathrm{RQ}-0.116 \Delta \mathrm{AF}(0.811) \quad(0.008) \\
& R^{2}=0.607, F=5.664, p \text {-value }=0.001, \text { Adjusted } R \text { Square }=0.500 .
\end{aligned}
$$

\section{Model Summary}

\begin{tabular}{|c|c|c|c|c|}
\hline Model & $\mathrm{R}$ & $\mathrm{R}$ Square & $\begin{array}{c}\text { Adjusted R } \\
\text { Square }\end{array}$ & $\begin{array}{c}\text { Std. Error } \\
\text { of the } \\
\text { Estimate }\end{array}$ \\
\hline 1 & .779 & .607 & .500 & .0086671 \\
\hline
\end{tabular}

a. Predictors: (Constant), $\triangle \mathrm{AF}, \Delta \mathrm{MS}, \Delta \mathrm{G}, \Delta \mathrm{ST}, \Delta \mathrm{RQ}, \Delta \mathrm{FD}$

\section{ANOVA}

\begin{tabular}{|c|c|c|c|c|c|}
\hline & $\begin{array}{c}\text { Sum of } \\
\text { Squares }\end{array}$ & $\mathrm{df}$ & $\begin{array}{c}\text { Mean } \\
\text { Square }\end{array}$ & $\mathrm{F}$ & Sig. \\
\hline Regression & .003 & 6 & .000 & 5.664 & .001 \\
\hline Residual & .002 & 22 & .000 & & \\
\hline Total & .004 & 28 & & & \\
\hline
\end{tabular}

a. Predictors: (Constant), $\Delta \mathrm{AF}, \Delta \mathrm{MS}, \Delta \mathrm{G}, \Delta \mathrm{ST}, \Delta \mathrm{RQ}, \Delta \mathrm{FDI}$

b. Dependent Variable: $\triangle \mathrm{GDP}$

\section{Coefficients}

\begin{tabular}{|c|c|c|c|c|c|}
\hline & $\begin{array}{c}\text { Unstandardized } \\
\text { Coefficients }\end{array}$ & & $\begin{array}{c}\text { Standardized } \\
\text { Coefficients }\end{array}$ & $\mathrm{t}$ & Sig. \\
\hline & $\mathrm{B}$ & $\begin{array}{c}\text { Std. } \\
\text { Error }\end{array}$ & Beta & & \\
\hline (Constant) & $3.665 \mathrm{E}-02$ & .004 & & 8.983 & .000 \\
\hline$\Delta \mathrm{G}$ & $7.931 \mathrm{E}-02$ & .034 & .316 & 2.356 & .028 \\
\hline$\Delta \mathrm{MS}$ & $6.712 \mathrm{E}-02$ & .020 & .486 & 3.429 & .002 \\
\hline$\Delta \mathrm{FDI}$ & $2.038 \mathrm{E}-03$ & .001 & .549 & 3.782 & .001 \\
\hline$\Delta \mathrm{ST}$ & $1.249 \mathrm{E}-03$ & .001 & .276 & 1.987 & .060 \\
\hline$\Delta \mathrm{RQ}$ & $-7.860 \mathrm{E}-04$ & .003 & -.034 & -.242 & .811 \\
\hline$\Delta \mathrm{AF}$ & -.116 & .040 & -.408 & -2.893 & .008 \\
\hline
\end{tabular}

a. Dependent Variable: $\triangle$ GDP

The Model-4A is statistically significant at $5 \%$ level. The reason is that $p$-value is less than 0.05 . 


\section{Model-4B:}

$\Delta \mathrm{GDP}_{\mathrm{t}}=0.0365+0.0789 \Delta \mathrm{G}+0.0679 \Delta \mathrm{MS}+0.00202 \Delta \mathrm{FDI}+0.00123 \Delta \mathrm{ST}-0.117 \Delta \mathrm{AF}$
p-values $\rightarrow \quad(0.025)$
$(0.002)$
$(0.001)$
(0.056)
$(0.007)$

$R^{2}=0.606, F=7.075$

$\mathrm{p}$-value $=0.000$

Adjusted R Square $=0.520$.

\section{Model Summary}

\begin{tabular}{|c|c|c|c|c|}
\hline Model & $\mathrm{R}$ & R Square & $\begin{array}{c}\text { Adjusted R } \\
\text { Square }\end{array}$ & $\begin{array}{c}\text { Std. Error } \\
\text { of the } \\
\text { Estimate }\end{array}$ \\
\hline 1 & .778 & .606 & .520 & .0084879 \\
\hline
\end{tabular}

a. Predictors: (Constant), $\triangle \mathrm{AF}, \Delta \mathrm{MS}, \Delta \mathrm{G}, \Delta \mathrm{ST}, \Delta \mathrm{FDI}$

\section{ANOVA}

\begin{tabular}{|c|c|c|c|c|c|}
\hline & $\begin{array}{c}\text { Sum of } \\
\text { Squares }\end{array}$ & $\mathrm{df}$ & $\begin{array}{c}\text { Mean } \\
\text { Square }\end{array}$ & $\mathrm{F}$ & Sig. \\
\hline Regression & .003 & 5 & .001 & 7.075 & .000 \\
\hline Residual & .002 & 23 & .000 & & \\
\hline Total & .004 & 28 & & & \\
\hline
\end{tabular}

a. Predictors: (Constant), $\triangle \mathrm{AF}, \Delta \mathrm{MS}, \Delta \mathrm{G}, \Delta \mathrm{ST}, \Delta \mathrm{FDI}$

b. Dependent Variable: $\triangle \mathrm{GDP}$

\section{Coefficients}

\begin{tabular}{|c|c|c|c|c|c|}
\hline & $\begin{array}{c}\text { Unstandardized } \\
\text { Coefficients }\end{array}$ & & $\begin{array}{c}\text { Standardized } \\
\text { Coefficients }\end{array}$ & $\mathrm{t}$ & Sig. \\
\hline & $\mathrm{B}$ & Std. Error & Beta & & \\
\hline (Constant) & $3.653 \mathrm{E}-02$ & .004 & & 9.210 & .000 \\
\hline$\Delta \mathrm{G}$ & $7.887 \mathrm{E}-02$ & .033 & .315 & 2.396 & .025 \\
\hline$\Delta \mathrm{MS}$ & $6.793 \mathrm{E}-02$ & .019 & .492 & 3.597 & .002 \\
\hline$\Delta \mathrm{FDI}$ & $2.017 \mathrm{E}-03$ & .001 & .543 & 3.875 & .001 \\
\hline$\Delta \mathrm{ST}$ & $1.228 \mathrm{E}-03$ & .001 & .271 & 2.014 & .056 \\
\hline$\Delta \mathrm{AF}$ & -.117 & .039 & -.410 & -2.971 & .007 \\
\hline
\end{tabular}

a. Dependent Variable: $\triangle$ GDP

The Model-4B is statistically significant at $5 \%$ level. The reason is that $\mathrm{p}$-value is less than 0.05 . 